* Doutor em Direito Civil pela Universidade do Estado do Rio de Janeiro (UERJ)

Professor Adjunto de Direito Civil da Faculdade de Direito da Universidade do Estado do Rio de Janeiro (UERJ)

E-mail: eduardo.nunesdesouza@ yahoo.com

**Doutorando em Direito Civil pela Universidade do Estado do Rio de Janeiro (UERJ)

E-mail: rodrigo.daguiasilva@gmail. com

\section{UMA APLICAÇÃO DA DISCIPLINA DO ENRIQUECIMENTO SEM CAUSA ÀS HIPÓTESES DE EXTINÇÃo CONTRATUAL: O PRAZO PRESCRICIONAL DA PRETENSÃo RESTITUTÓRIA}

\author{
AN APPLICATION OF THE DISCIPLINE OF UNJUST ENRICHMENT \\ TO THE CHANCES OF CONTRACTUAL TERMINATION: THE \\ PRESCRIPTIVE PERIOD OF THE RESTITUTORY CLAIM
}

\section{Eduardo Nunes de Souza* Rodrigo da Guia Silva**}

Como citar: SOUZA, Eduardo Nunes de; SILVA, Rodrigo da Guia. Uma aplicação da disciplina do enriquecimento sem causa às hipóteses de extinção contratual: o prazo prescricional da pretensão restitutória. Scientia Iuris, Londrina, v. 25, n. 2, p. 83106, jul. 2021. DOI 10.5433/21788189.2021v25n2p83. ISSN: $2178-8189$

Resumo: O presente estudo parte da teoria geral do enriquecimento sem causa como uma das três principais fontes de obrigações no direito civil brasileiro (ao lado da fonte negocial e da responsabilidade civil) para, em seguida, demonstrar a relevância desse pressuposto para a correta qualificação de certos deveres de restituir que, embora não derivados da cláusula geral de vedação ao enriquecimento injusto, também pertencem à mesma fonte obrigacional. Como exemplo prático de aplicação, o artigo aborda alguns casos de pretensão restitutória decorrentes de extinção contratual, em que a incorreta qualificação jurisprudencial da fattispecie tem levado a equívocos quanto à identificação do prazo prescricional a ela aplicável. A metodologia utilizada foi a revisão doutrinária e a pesquisa jurisprudencial.

Palavras-chave: enriquecimento sem causa; obrigação de restituir; fontes das obrigações; prescrição; resolução contratual.

\begin{abstract}
This study starts from the general theory of unjust enrichment as one of the three main sources of obligations in Brazilian civil law (together with the business source and civil liability) and then demonstrates the relevance of this assumption for the correct qualification of certain duties of restitution that, although not derived from the general clause of prohibition of unjust enrichment, also belong to the same source of obligation. As a practical example of application, the article addresses some cases of restitutionary claims arising from contractual termination, in which the incorrect jurisprudential qualification of the fattispecie
\end{abstract}


has led to misunderstandings as to the identification of the applicable statute of limitations. The methodology used was literature review and jurisprudential research

Keywords: unjust enrichment; duty of restitution; sources of obligations; prescription; contractual extinction. 


\section{INTRODUÇÃO}

A vedação ao enriquecimento sem causa experimentou uma relevante evolução na transição entre os regimes do Código Civil brasileiro de 1916 e da codificação atual. O instituto, antes reduzido à categoria dos princípios gerais do direito (mecanismos eminentemente residuais voltados a colmatar lacunas normativas) ${ }^{1}$ e extraído da ratio legis de normas jurídicas esparsas, passou a estar expressamente positivado pelo Capítulo IV ("Do Enriquecimento sem Causa) do Título VII ("Dos Atos Unilaterais”) do Livro dedicado pelo Código Civil de 2002 ao Direito das Obrigações. ${ }^{2}$ No regime atual, a vedação ao enriquecimento sem causa ganhou, inclusive, uma enunciação expressa, prevista pelo art. 884 do Código Civil, que dispõe: “Aquele que, sem justa causa, se enriquecer à custa de outrem, será obrigado a restituir o indevidamente auferido, feita a atualização dos valores monetários".

Tal opção do codificador de 2002 traduz a consagração de uma autêntica cláusula geral do dever de restituir no direito brasileiro (SILVA, 2020), com a polivalência e a tendência expansiva ínsitas à textura aberta dessa técnica normativa (COSTA, 2018, p. 146 e ss.). Por outro lado, e ao contrário do que tal escolha legislativa poderia sugerir, embora a mencionada cláusula geral tenha adquirido proeminência no tratamento da matéria, não se tornou a técnica normativa exclusiva a disciplinar o enriquecimento sem causa, que continua contando com previsões esporádicas do dever de restituir, estipuladas na forma da técnica regulamentar. ${ }^{3}$ Em outros termos, a despeito da relevância da cláusula geral prevista pelo art. 884 do Código Civil, a disciplina do enriquecimento sem causa no direito civil brasileiro não se resume a ela.

Uma compreensão mais apurada desse cenário pode ser obtida assumindo-se como premissa a qualificação funcional das obrigações no direito civil. Este é o ponto de partida do presente estudo, que, ao apresentar o perfil funcional da obrigação de restituir, pretende, em seguida, evidenciar a importância da sua correta diferenciação em face das demais fontes obrigacionais. Como exemplo central, o estudo apresentará as consequências dessa qualificação funcional adequada em relação ao prazo prescricional da pretensão restitutória, questão reiteradamente abordada na jurisprudência pátria, nem sempre com o tratamento técnico ideal. É o que se passa a expor.

\section{A CLÁUSUla GERAL DE VEDAÇÃO AO ENRIQUECIMENTO SEM CAUSA E AS PREVISÕES ESPECÍFICAS DA OBRIGAÇÃO DE RESTITUIR}

Não é recente o entendimento de que a percepção das similitudes e distinções funcionais entre as diferentes espécies de obrigações permite identificar a normativa mais diretamente relacionada a cada específica obrigação com a qual se depara o intérprete. De fato, apenas a partir da consideração do perfil funcional da relação obrigacional se faz possível atingir concretamente a satisfação dos interesses merecedores de tutela que estejam em jogo em cada hipótese. ${ }^{4}$ Nesse particular, parece correto considerar que $\mathrm{o}$ interesse do titular de um direito obrigacional filia-se, na maior parte dos casos, a pelo 
menos três ordens distintas de interesses: seja à realização das expectativas nascidas de compromissos assumidos, seja à reparação dos danos causados, seja, ainda, à reversão de transferências patrimoniais injustificadas, a depender da hipótese fática que originou a obrigação (NORONHA, 2013, p. 440).

Em outros termos, a análise funcional das obrigações civis torna possível a sua sistematização, na generalidade dos casos, em torno de três grandes regimes, vinculados à fonte de cada obrigação: negócio jurídico, dano injusto e enriquecimento sem causa (ESPÍNOLA, 2005, p. 75-77). Nessa direção, reconhece-se uma tripartição funcional das obrigações, podendo-se apartar uma função, por assim dizer, executória (de um negócio legitimamente celebrado), uma função reparatória (de um dano injustamente sofrido) e, por fim, uma função restitutória (de um enriquecimento injustamente auferido). ${ }^{5}$ Tal sistematização permite ao intérprete identificar o regime jurídico regente de certa relação obrigacional a partir da vinculação funcional da específica hipótese de obrigação aos regimes obrigacionais fundamentais consagrados pelo direito brasileiro (SILVA, 2018a, item 1.2.2).

À luz dessa tripartição funcional, torna-se mais simples compreender, por exemplo, as quatro categorias (muito distintas entre si) reunidas pelo Código Civil de 2002 sob a alcunha de "atos unilaterais" (Título VII do Livro I da Parte Especial). A primeira delas - a promessa de recompensa - não parece oferecer dificuldade significativa: reconhece-se, desde a vigência do Código Civil de 1916, sua natureza de negócio jurídico unilateral. ${ }^{6}$ A gestão de negócios, por sua vez, subdivide-se em hipóteses particulares, conforme a gestão seja ou não ratificada e, neste último caso, seja ou não reputada útil ao dono do negócio: "[...] a gestão ratificada tem consequências similares ao contrato de mandato; a não ratificada, mas útil, gera obrigação de restituição por enriquecimento sem causa; a não ratificada e tida como não útil gera responsabilidade civil". ${ }^{7}$ A fonte obrigacional, portanto, dependerá de se aferir, em concreto, o contexto da gestão. O pagamento indevido, por sua vez, que normalmente se traduz em ato jurídico em sentido estrito, gera obrigação funcionalmente destinada à restituição do enriquecimento sem causa. ${ }^{8}$

Diversamente desses casos, o enriquecimento sem causa de que trata o art. 884 do Código Civil, embora referido nominalmente pelo legislador como quarta fattispecie de "ato unilateral", na realidade traduz "pura e simplesmente uma das três grandes categorias em que podem ser repartidas

5 Fernando Noronha assevera: "Falar na diversidade de funções que desempenham as obrigações que acabamos de caracterizar como autônomas, é o mesmo que nos reportarmos à diversidade de interesses que são prosseguidos em cada uma delas. Assim, a tripartição entre obrigações negociais, de responsabilidade civil e de enriquecimento sem causa constitui a divisão fundamental das obrigações, do ponto de vista dos interesses tutelados" (NORONHA, 2013, p. 439). Na mesma linha de sentido, v. Miragem (2011, p. 385-402). Registre-se que, naturalmente, um negócio jurídico pode prever obrigações de restituir - mais usualmente referidas como obrigações de restituir (ou devolver) coisa certa. A restituição relevante ao presente estudo, diversamente, é aquela funcionalmente direcionada não à promoção de um interesse contratualmente ajustado, mas sim à recomposição de um patrimônio injustificadamente beneficiado.

6 "Entende-se como promessa de recompensa o negócio jurídico unilateral pelo qual se estipula uma gratificação ou recompensa pelo preenchimento de certa condição, ou pela prestação de certo serviço, anunciado publicamente, de maneira a obrigar o promitente a cumprir o prometido. A natureza jurídica da promessa de recompensa constitui ponto pacífico na doutrina brasileira desde o CC1916" (TEPEDINO; BARBOZA; MORAES, 2012, p. 687).

7 NORONHA, 2013, p. 432. Em sentido semelhante, v. Konder (2005, p. 394).

8 Assim conclui, na doutrina italiana, Pietro Perlingieri (2014, p. 299, tradução livre): “A repetição do pagamento indevido é uma ação restitutória." O autor arremata: "O direito à repetição daquilo que se pagou indevidamente não tem natureza ressarcitória, não sendo o comportamento do accipiens por si ilegítimo e causador de dano" (PERLINGIERI, 2014, nota de rodapé n. 808, tradução livre). Na doutrina brasileira, Silvio Rodrigues assevera: "O pagamento indevido constitui no plano teórico, apenas um capítulo de assunto mais amplo, que é o enriquecimento sem causa. Este representa o gênero, do qual aquele não passa de espécie" (RODRIGUES, 1964, p. 185). Na mesma linha de sentido, afirma-se: "Enriquecimento sem causa e pagamento indevido, a rigor, são gênero e espécie. A técnica do Código Civil de 2002 desconsiderou este aspecto, e fez a espécie preceder o gênero" (MIRAGEM, 2017, p. 81). 
todas as obrigações." (NORONHA, 2013, p. 432). Em outros termos, não cogitou o legislador neste dispositivo de um ato específico originador da obrigação restitutória, mas, em vez disso, descreveu uma circunstância ampla o suficiente para que nela se subsumam incontáveis casos particulares de restituições. No direito positivo brasileiro, assim, a vedação ao enriquecimento sem causa manifestase tanto por meio dessa normativa ampla constante do art. 884 do Código Civil quanto por previsões legais específicas de restituição que ostentem a função restitutória (como algumas das hipóteses elencadas no referido Título VII e correspondentes a atos específicos). ${ }^{9}$

O regime da vedação ao enriquecimento sem causa não se esgota, portanto, na cláusula geral do dever de restituir, da mesma forma como, por exemplo, o regime da responsabilidade civil certamente não se esgota nas cláusulas gerais do dever de indenizar. O cotejo com a responsabilidade civil, neste ponto, facilita a compreensão da sistemática ora comentada: não há grande dissenso quanto ao entendimento de que as cláusulas gerais contidas no caput e no parágrafo único do art. 927 (responsabilidade civil subjetiva e objetiva, respectivamente) convivem com previsões específicas do dever de indenizar, sem que se retire destas últimas a qualificação de fontes de obrigação autenticamente reparatória. ${ }^{10}$ Basta pensar, ilustrativamente, nas diversas disposições específicas que reconhecem o direito da parte lesada a cobrar perdas e danos (v., entre outros, os arts. 12, 146, 148, 149, 154, 155, 234, 236, 239, 247, 248, 251, 254 e 255, 389, 395 e 402 do Código Civil), muito embora essa prerrogativa já se extraia, em princípio, da simples incidência das referidas cláusulas gerais. ${ }^{11}$

Previsões como essas, muito comuns no direito brasileiro, por vezes apenas reafirmam a existência do dever de indenizar (com frequência, em casos nos quais o legislador quer demarcar bem a independência entre esse dever e outras obrigações funcionalmente diversas); em outras ocasiões, porém, tais regras efetivamente modificam ou afastam os requisitos gerais dessa fonte obrigacional. Não se questiona, por exemplo, a natureza indenizatória das hipóteses da chamada responsabilidade indireta prevista pelos arts. 932 e 933 do Código Civil, muito embora elas não decorram imediatamente da cláusula geral consagrada pelo parágrafo único do art. $927 .{ }^{12}$ Assim

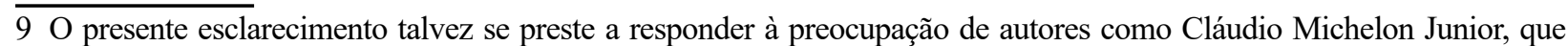
sustenta uma tripartição das fontes das obrigações em que o enriquecimento sem causa assume a conotação de mera espécie da fonte mais abrangente que denominou "direito restitutório"; o autor identifica, nesse sentido, "[...] três fontes independentes de obrigação, quais sejam (a) as declarações de vontade, (b) a ocorrência de danos imputáveis e (c) a migração injustificada de bens ou direitos de um patrimônio a outro" (MICHELON JUNIOR, 2007, p. 15). O autor afirma, ao analisar o Título VII do Livro I da Parte Especial do Código Civil de 2002: "Um mesmo princípio jurídico fundamenta a existência dos institutos da actio contraria na gestão de negócios (Capítulo II), do pagamento indevido (Capítulo III) e do enriquecimento sem causa (Capítulo IV), qual seja o princípio da conservação estática dos patrimônios. A adoção desse princípio é o que explica a reunião dos três institutos em um mesmo título do novo Código Civil. Em última análise, a configuração estrutural do título em comento representa o reconhecimento pelo codificador brasileiro de uma fonte autônoma de obrigações que não orbita em torno da noção de ato voluntário e que, ao mesmo tempo, é tertium genus em relação à distinção entre obrigações resultantes de declarações de vontade e obrigações resultantes de responsabilidade civil" (MICHELON JUNIOR, 2007, p. 17-18). Referida formulação, pautada na rejeição da unificação funcional das obrigações restitutórias em torno da vedação ao enriquecimento sem causa e na primazia de um suposto princípio de duvidosa juridicidade (o "princípio da conservação estática dos patrimônios"), além de não contar, aparentemente, com qualquer substrato positivo no direito brasileiro, parece padecer da dificuldade de compreensão da distinção entre o regime (ou fonte) geral da vedação ao enriquecimento sem causa e a cláusula geral do dever de restituir.

10 A propósito do sistema dualista de responsabilidade civil consagrado no direito brasileiro, v., por todos, Tepedino (2008, p. 205) e Schreiber (2015, p. 19 e ss).

11 A identificar a natureza indenizatória da pretensão ao pagamento de perdas e danos, v., por todos, Alvim (1965, p. 169) e ss.; Gomes (1976, p. 188-190) e Santos (1986, p. 262).

12 Para uma análise do desenvolvimento dogmático da responsabilidade indireta, v., por todos, Pereira (2016, p. 119) e Dias (2012, p. 629 e ss). Contemporaneamente, v., ainda, Souza (2018), item 4. 
também ocorre no enriquecimento sem causa: a vinculação de uma obrigação à fonte restitutória não se resume às hipóteses diretamente decorrentes da cláusula geral contida no art. 884 do Código Civil. ${ }^{13}$ Ainda ilustrativamente, a norma que prevê o dever de indenizar do transportador independentemente do fato de terceiro (art. 735 do Código Civil), embora claramente estipule obrigação reparatória, não apenas está prevista em dispositivo próprio como, mais ainda, restringe e particulariza a forma como a cláusula geral de responsabilidade civil objetiva (art. 927, parágrafo único) trata do requisito causal. ${ }^{14}$ Semelhante linha de raciocínio há de ser adotada na compatibilização entre regras excepcionais sobre o dever de restituir e a cláusula geral do enriquecimento sem causa. ${ }^{15}$

A disposição deliberadamente genérica do art. 884 do Código Civil, nessa direção, convive com previsões específicas de obrigações restitutórias - como aquelas constantes, dentre muitos outros, dos arts. 182, 236 e 239 do Código Civil, além, por certo, das previsões atinentes ao pagamento indevido (arts. 878-883 do Código Civil). ${ }^{16}$ Constata-se, assim, que, na contramão de possíveis modelos teóricos que restrinjam a restituição a previsões legais específicas, o direito brasileiro estabelece a possibilidade de deflagração do dever de restituir em hipóteses fáticas não contempladas por norma particular, mas que preenchem os requisitos gerais do art. 884 do Código Civil. Prevê, assim, o legislador pátrio, a um só tempo, tanto o regime geral das obrigações restituitórias quanto as suas eventuais modificações diante de previsões legais específicas.

\section{O PROBLEMA DA INCOMPREENSÃO JURISPRUDENCIAL ACERCA DA PRETENSÃO RESTITUTÓRIA PREVISTA POR DISPOSIÇÕES LEGAIS ESPECÍFICAS}

A rigor, a qualificação do enriquecimento sem causa como uma das grandes fontes obrigacionais (ao lado dos negócios jurídicos e da responsabilidade civil) já poderia ser sustentada mesmo sob a égide do Código Civil de 1916 - vez que, partindo da perspectiva funcional, tal entendimento independe da disposição topográfica de matérias escolhida pelo codificador. No entanto, com a consagração da cláusula geral do enriquecimento sem causa pelo atual art. 884 do Código Civil, essa concepção revela-se ainda mais deliberada por parte do legislador, que passou a estruturar a fonte obrigacional restitutória utilizando o mesmo recurso técnico com o qual já estruturava, desde o regime anterior, a fonte indenizatória. ${ }^{17}$ Por outro lado, a existência de uma cláusula geral do dever de restituir, por representar experiência ainda recente no direito brasileiro, tem enfrentado grave incompreensão na práxis jurídica, de longa data acostumada com a crença de que o enriquecimento sem causa teria utilidade residual (e, muitas vezes, meramente retórica) no direito das obrigações.

\footnotetext{
13 Para um relato de semelhante experiência, na experiência estrangeira, a propósito da positivação do enriquecimento sem causa pela técnica de cláusula geral, v., no direito português, Leitão (1996, p. 32 e ss) e, no direito italiano, Benedetti (1959, p. 1.653).

14 Análise mais detida sobre a hipótese, que exemplifica os chamados regimes de responsabilidade civil agravada, foi desenvolvida em Souza (2018, p. 87-89).

15 A destacar a similitude entre a responsabilidade civil e a vedação ao enriquecimento sem causa na experiência italiana no tocante à presença de uma cláusula geral, v. Franzoni (2010, p. 768).

16 Semelhante fenômeno é identificado, na experiência portuguesa, por Leitão (1996, p. 36-37).

17 Sobre a coexistência das cláusulas gerais de responsabilidade civil com disposições específicas sobre o dever de indenizar no direito brasileiro, v. Souza (2018, passim) e, em particular, item 5.
} 
Nesse cenário de incompreensão, a positivação da cláusula geral do dever de restituir, que poderia representar a consagração do enriquecimento sem causa como um dos grandes regimes obrigacionais, acabou acarretando, na prática, o efeito oposto: acostumada a uma aparente subsidiariedade do enriquecimento sem causa, ${ }^{18}$ a jurisprudência brasileira continua tratando as previsões específicas do dever de restituir (como a repetição do pagamento indevido, o reembolso pela gestão de negócios útil não ratificada ou a devolução do equivalente diante da impossibilidade superveniente da obrigação) como hipóteses totalmente autônomas. Em outros termos, tais previsões, em vez de serem filiadas à fonte obrigacional geral do enriquecimento sem causa (como determina seu perfil funcional), são vistas pelo intérprete, muitas vezes, como escolhas arbitrárias do legislador, isto é, como se cada uma fosse dotada de uma função sui generis e representasse um caso isolado no ordenamento.

A cláusula geral do enriquecimento sem causa, nesse cenário, em vez de reforçar a unidade funcional que aproxima todas as hipóteses do dever de restituir (previstas por normas específicas ou não), acabou por reforçar, equivocadamente, o isolamento dos casos particulares na práxis judicial. Assim, em lugar de concluir que hipóteses como a devolução do pagamento indevido são especificações do regime geral do dever de restituir (o qual, por sua vez, tem como fonte a vedação ao enriquecimento sem causa), a jurisprudência brasileira frequentemente sustenta a tese oposta: a de que, justamente por estarem positivadas como institutos particulares, tais hipóteses não poderiam se relacionar com o enriquecimento sem causa, pois este último seria um instituto autônomo e excepcional, apenas aplicável à míngua de norma mais específica. Semelhante confusão tem levado à consagração de diversos entendimentos (muitas vezes consolidados em enunciados sumulares) totalmente dissonantes com a sistemática concebida pelo codificador para as fontes obrigacionais.

Pense-se, por exemplo, na discussão submetida à apreciação do Superior Tribunal de Justiça (EREsp 1.523.744/RS), consistente em definir se a pretensão de repetição de indébito ${ }^{19}$ no

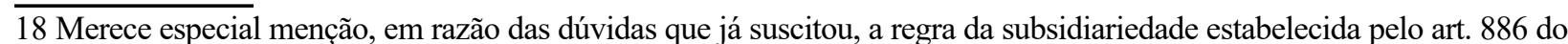
Código Civil. A subsidiariedade ostenta, no contexto contemporâneo, a qualidade de pressuposto negativo de incidência da cláusula geral do dever de restituir, de modo a se assegurar o respeito à disciplina própria dispensada pelo legislador ordinário a hipóteses específicas de restituição. À atuação da cláusula geral do dever de restituir não basta, portanto, a demonstração dos requisitos ou pressupostos positivos tradicionalmente elencados - enriquecimento, obtenção à custa de outrem e ausência de justa causa -, afigurando-se igualmente relevante o respeito à regra da subsidiariedade. Tais observações em nada afetam, por outro lado, a qualificação da obrigação restitutória à luz da vedação ao enriquecimento sem causa. Seja decorrente de uma previsão legal específica, seja decorrente da cláusula geral do art. 884 do Código Civil, a obrigação se vinculará ao regime geral da vedação ao enriquecimento sem causa quando ostentar a função restitutória que distingue esta das demais fontes das obrigações no direito civil. Em outros termos, não se justificam posicionamentos doutrinários que buscam desvincular obrigações de cunho claramente restitutório em relação à sua fonte (a vedação ao enriquecimento sem causa), simplesmente invocando o argumento da subsidiariedade. Para um desenvolvimento da compreensão da subsidiariedade como pressuposto negativo de configuração do dever de restituir, v. Silva (2018), item 2.4 .

19 Vale destacar, desde logo, que a controvérsia de fundo versava, ainda que acidentalmente, sobre um ponto que não costuma ter a sua relevância devidamente ressaltada. Trata-se da dúvida sobre submeter-se ou não a pretensão de "devolução em dobro" do indébito ao mesmo prazo prescricional aplicável à pretensão de devolução simples. Essa questão - digna de mais detida reflexão, o que não se lograria realizar nesta sede - assume contornos delicados a partir do reconhecimento de que o perfil funcional restitutório que caracteriza a obrigação de repetição do indébito (ou seja, a obrigação de devolver o valor indevidamente auferido) não parece idôneo a explicar também a obrigação de pagar a parcela atinente ao dobro. A condenação ao pagamento da parcela sobressalente parece traduzir, em realidade, uma autêntica punição à pessoa beneficiada pelo pagamento indevido, o que talvez explique a relevância assumida pela prova do engano justificável (em juízo valorativo acerca da reprovabilidade ou não da conduta do agente). Ao propósito, já se pôde destacar: "a conclusão sobre a diversidade de perfis funcionais entre a obrigação de devolução simples (esta, sim, de cunho nitidamente restitutório) e aquela de devolução em dobro reclama investigação da civilística acerca da disciplina jurídica aplicável especificamente à pretensão de ‘devolução’ da parcela sobressalente, a começar pelo prazo prescricional 
âmbito dos serviços de telefonia deveria se sujeitar ao prazo prescricional trienal da "pretensão de ressarcimento de enriquecimento sem causa" (art. 206, $\S 3^{\circ}$, IV, do Código Civil) ${ }^{20}$ ou se, ao revés, deveria ser regida pelo prazo prescricional geral decenal que o legislador dispensa às hipóteses não submetidas a outro prazo específico (art. 205 do Código Civil). ${ }^{21} \mathrm{O}$ recurso foi julgado, inicialmente, pela Terceira Turma do Tribunal, a qual concluiu, unanimemente, que o prazo prescricional geral de dez anos não poderia ser invocado em razão da existência de prazo prescricional específico idôneo a reger a pretensão de repetido de indébito - qual seja, o prazo trienal referente ao enriquecimento sem causa. ${ }^{22}$

Cumpre registrar, desde logo, que a dúvida não diz respeito propriamente à identificação de qual seria o prazo prescricional da pretensão de restituição fundada no enriquecimento sem causa, uma vez que para tal hipótese o legislador previu expressamente o prazo prescricional trienal (art. 206, § $3^{\circ}$, IV, do Código Civil). Trata-se, em realidade, de definir se essa previsão normativa abarca a pretensão de repetição de indébito, muito embora essa restituição não decorra diretamente da cláusula geral do art. 884 do Código Civil. Em caso afirmativo, concluir-se-á pelo potencial expansivo do mencionado prazo prescricional trienal; em caso negativo, tender-se-á a reconhecer a incidência do prazo prescricional geral de dez anos de que trata o art. 205 sobre tais hipóteses, ${ }^{23}$ como fez o STJ no caso mencionado.

Irresignada, uma das autoras da ação interpôs embargos de divergência. A Corte Especial do STJ viu-se, então, diante da necessidade de uniformizar a interpretação da legislação infraconstitucional na matéria, a fim de superar dissídio jurisprudencial entre as Turmas integrantes da Primeira Seção e as Turmas integrantes da Segunda Seção do Tribunal. De fato, uma consulta ao repositório jurisprudencial da Corte revela que os referidos órgãos julgadores não raramente alcançavam conclusões nitidamente opostas no tocante ao prazo prescricional regente da pretensão de repetição de indébito no âmbito de serviços de telefonia - ora no sentido da aplicação do prazo prescricional trienal do enriquecimento sem causa, ${ }^{24}$ ora no sentido da aplicação do prazo prescricional

sobre ela incidente. Trata-se, em suma, de reconhecer que a eventual identificação de função punitiva de certas obrigações parece desautorizar a aplicação automática do idêntico regime jurídico dispensado às obrigações de perfil restitutório a elas associadas, a exemplo do que sucede a propósito da definição do prazo prescricional de três anos da pretensão de restituição do enriquecimento sem causa" (SILVA, 2018, p. 115-116). Para o desenvolvimento da problemática, v., ainda, Souza e Silva (2018), item 4.

20 In verbis: "CC. Art. 206. Prescreve: [...] $\S 3^{\circ}$ Em três anos: [...] IV - a pretensão de ressarcimento de enriquecimento sem causa".

21 In verbis: "CC. Art. 205. A prescrição ocorre em dez anos, quando a lei não lhe haja fixado prazo menor".

22 O acórdão restou assim ementado: "Agravo regimental no recurso especial. Empresa de telefonia. Cobrança indevida. Repetição do indébito. Prescrição trienal. Consonância entre o acórdão recorrido e o entendimento desta corte. 1. As Turmas da Segunda Seção do Superior Tribunal de Justiça entendem que incide o prazo prescricional de 3 (três) anos, previsto no art. 206, $\S 3^{\circ}$, V [rectius: IV], do Código Civil, na ação de repetição de indébito por cobrança indevida de valores referentes a serviços não contratados promovida por empresa de telefonia. 2. Agravo regimental não provido" (STJ, $3^{\mathrm{a}}$ T., AgRg no REsp 1.523.744/RS, Rel. Min. Ricardo Villas Bôas Cueva, julg. 10.3.2016, publ. 28.3.2016).

23 A ilustrar a proposta de aplicação do prazo prescricional geral, veja-se a conclusão de Judith Martins Costa (2015, p. 278) a propósito do pagamento indevido: "[...] as obrigações resultantes de pagamento indevido são enquadradas na regra geral dos prazos prescricionais prevista no caput do art. 205, ou seja, 10 anos [...]."

24 V., ilustrativamente, STJ, $3^{\mathrm{a}}$ T., AgInt no REsp 1.585.124/RS, Rel. Min. Moura Ribeiro, julg. 13.9.2016, publ. 20.9.2016; STJ, $3^{\mathrm{a}}$ T., AgInt no AREsp 708.688/RS, Rel. Min. Marco Aurélio Bellizze, julg. 19.5.2016, publ. 31.5.2016; e STJ, 4ª T., AgRg no AREsp 729.090/RS, Rel. Min. Luis Felipe Salomão, julg. 27.10.2015, publ. 5.11.2015. 
geral decenal, ${ }^{25}$ verificando-se, de todo modo, certa tendência à prevalência desta última posição. ${ }^{26}$ Ao apreciar os EREsp 1.523.744/RS, em julgamento tomado por maioria, a Corte Especial do STJ concluiu pela aplicabilidade do prazo prescricional decenal (estabelecido em caráter supletivo pelo art. 205 do Código Civil) para a regência dos casos de repetição de indébito no âmbito dos serviços de telefonia. ${ }^{27}$ Afirmou-se que faltaria ao caso um dos requisitos para que se pudesse admitir a configuração de enriquecimento sem causa nos termos do art. 884 do Código Civil, qual seja: a ausência de causa jurídica. A existência prévia de um contrato celebrado pelas partes representaria, segundo se aduziu, a presença de uma causa jurídica obstativa da configuração da hipótese de incidência do dispositivo legal mencionado. ${ }^{28}$ Asseverou-se, ainda, que o caráter subsidiário estabelecido pelo art. 886 do Código Civil impediria a atração da disciplina do enriquecimento sem causa para a solução de uma questão regida pela disciplina própria do pagamento indevido. ${ }^{29}$

Nenhum dos dois argumentos, porém, merece prosperar. Em primeiro lugar, compreender o contrato celebrado pelas partes (usuário e fornecedor do serviço de telefonia) como causa da vantagem patrimonial auferida pela fornecedora diante de serviços comprovadamente não contratados (e não usufruídos) revela-se tão equivocado quanto afirmar que a ausência de consenso gera as mesmas obrigações que o consenso geraria se houvesse sido alcançado regularmente. O contrato apenas tem o condão de justificar a exigibilidade das obrigações por ele estabelecidas. ${ }^{30}$ Se o intérprete já tem certeza quanto à inexigibilidade de um pagamento jamais contemplado pelo contrato, não há motivo

25 V., ilustrativamente, STJ, $1^{\mathrm{a}}$ T., EDcl no REsp 1.446.597/DF, Rel. Min. Napoleão Nunes Maia Filho, julg. 15.5.2018, publ. 23.5.2018; STJ, $2^{\mathrm{a}}$ T., REsp 1.660.377/RS, Rel. Min. Herman Benjamin, julg. 6.6.2017, publ. 19.6.2017; e STJ, $1^{\mathrm{a}}$ T., AgInt no REsp 1.637.547/RS, Rel. Min. Regina Helena Costa, julg. 21.3.2017, publ. 31.3.2017.

26 "1. Segundo a jurisprudência vigente neste Sodalício, é de 10 (dez) anos o prazo prescricional aplicável às ações de repetição de indébito para ressarcimento de valores cobrados indevidamente por empresas telefônicas" (STJ, C.E., AgInt nos EREsp 1.523.591/RS, Rel. Min. Jorge Mussi, julg. 16/08/2017, publ. 24.8.2017). No mesmo sentido, v. STJ, C.E., AgInt nos EREsp 1.585.124/RS, Rel. Min. Og Fernandes, julg. 15.3.2017, publ. 21.3.2017; e STJ, C.E., EAREsp 758.676/ RS, Rel. Min. Laurita Vaz, julg. 18.5.2016, publ. 15.6.2016.

27 Vale destacar o trecho final da ementa da decisão: "4. Embargos de divergência providos, de sorte a vingar a tese de que a repetição de indébito por cobrança indevida de valores referentes a serviços não contratados, promovida por empresa de telefonia, deve seguir a norma geral do lapso prescricional (10 anos - art. 205, Código Civil/2002), a exemplo do que decidido e sumulado (Súmula 412/STJ), no que diz respeito ao lapso prescricional para repetição de indébito de tarifas de água e esgoto" (STJ, C.E., EREsp 1.523.744/RS, Rel. Min. Og Fernandes, julg. 20.2.2019, publ. 13.3.2019).

28 A afirmação da existência de uma causa (no sentido de título jurídico), a impedir a aplicação do art. 884 do Código Civil, aparece, por exemplo, no voto da Ministra Nancy Andrighi. Nos termos da fundamentação por ela aduzida, "não parece o mais correto considerar que uma cobrança indevida, no contexto de uma relação de consumo de serviço de telefonia, seja uma forma de enriquecimento sem causa, pois, a rigor, nessas situações há uma causa, um fundamento, que é o contrato existente entre consumidor e operadora".

29 Esses pontos centrais da fundamentação da decisão encontram-se bem sintetizados no voto do relator: "A pretensão de enriquecimento sem causa (ação in rem verso) possui como requisitos: enriquecimento de alguém; empobrecimento correspondente de outrem; relação de causalidade entre ambos; ausência de causa jurídica; inexistência de ação específica. Trata-se, portanto, de ação subsidiária que depende da inexistência de causa jurídica. [...] A discussão sobre a da cobrança indevida de valores constantes de relação contratual e eventual repetição de indébito não se enquadra na hipótese do art. $206, \S 3^{\circ}$, IV, do Código Civil/2002, seja porque a causa jurídica, em princípio, existe (relação contratual prévia em que se debate a legitimidade da cobrança), seja porque a ação de repetição de indébito é ação específica. [...] Verifica-se, pois, que o prazo prescricional estabelecido no art. $206, \S 3^{\circ}$, IV, do Código Civil/2002 deve ser interpretado de forma restritiva, para os casos subsidiários de ação de in rem verso" (STJ, C.E., EREsp 1.523.744/RS, Rel. Min. Og Fernandes, julg. 20.2.2019, publ. 13.3.2019). Vale destacar que o caso foi apreciado pela Corte Especial do STJ conjuntamente com outros casos cujo cerne versava sobre a mesma questão (a definição do prazo prescricional aplicável à pretensão de repetição de indébito no âmbito dos serviços de telefonia), tendo sido proclamada a mesma tese (no sentido da incidência do prazo prescricional decenal) para todos eles: STJ, C.E., EAREsp 750.497/RS, Rel. Min. Og Fernandes, julg. 20.2.2019, publ. 11.6.2019; STJ, C.E., EAREsp 738.991/RS, Rel. Min. Og Fernandes, julg. 20.2.2019, publ. 11.6.2019; STJ, C.E., EAREsp 622.503/RS, Rel. Min. Og Fernandes, julg. 20.2.2019, publ. 11.6.2019.

$30 \mathrm{Ou}$, por certo, aquelas decorrentes da lei para assegurar a promoção do programa contratual entabulado pelas partes, no âmbito da chamada heterointegração dos contratos. Ulteriores considerações sobre a relação entre a integração do conteúdo negocial pela fonte legal e sua relevância para a concretização do próprio programa contratual foram desenvolvidas em Souza (2019), item 4. 
para considerar esse mesmo contrato como título justificador da transferência patrimonial almejada pela parte que já se sabe não ter razão. ${ }^{31}$

Em segundo lugar, a regra da subsidiariedade prevista pelo art. 886 do Código Civil para o regime geral do enriquecimento sem causa, ao contrário do que se costuma supor, tem como único propósito o de evitar que a disciplina da cláusula geral do dever de restituir seja aplicada em detrimento das normas que o legislador houver estabelecido para hipóteses específicas de obrigações restitutórias. Desse modo, a existência de uma disciplina legal própria para o pagamento indevido (arts. 876-883 do Código Civil e art. 42 do Código de Defesa do Consumidor), como deveria ser intuitivo, impede a invocação indiscriminada da cláusula geral do dever de restituição estabelecida pelo art. 884 do Código Civil. Proíbe-se, assim, a aplicação direta da cláusula geral nas hipóteses em que o legislador houver dispensado disciplina própria para a específica obrigação restitutória, sem que disso nada se pode extrair sobre a qualificação funcional das variadas obrigações restitutórias. ${ }^{32}$ Do mesmo modo, como esclarecido anteriormente, embora nenhuma regra específica assim preveja, não se podem aplicar os requisitos previstos nas cláusulas gerais de responsabilidade civil se houver disposição específica que module tais requisitos em certo caso concreto.

Em outros termos, a subsidiariedade estabelecida pelo art. 886 do Código atua, em realidade, como pressuposto negativo de incidência da cláusula geral do dever de restituir. A regra, portanto, em nada afeta a abrangência do enriquecimento sem causa como regime jurídico obrigacional, do que decorre a impossibilidade de a regra da subsidiariedade obstar a adequada qualificação das obrigações que ostentem o perfil funcional restitutório como deveres autenticamente oriundos dessa fonte. Eis o desacerto fundamental do entendimento subjacente à conclusão do STJ: embora a regra da subsidiariedade impeça a aplicação direta da cláusula geral do art. 884 do Código Civil, ela nada diz acerca da qualificação das variadas hipóteses de obrigações restitutórias à luz da vedação ao enriquecimento sem causa, de modo que nada impede a submissão de uma específica pretensão restitutória (como a deflagrada pelo pagamento indevido) ao prazo prescricional incidente sobre as diversas pretensões que tenham em comum o perfil funcional de restituição do enriquecimento sem causa.

O tema do prazo prescricional da pretensão à repetição de indébito segue não pacificado no âmbito da Corte Superior, encontrando-se, hoje, pendente de julgamento o Tema Repetitivo n. 954, que tem por objeto, dentre outros, o "prazo prescricional incidente em caso de pretensão à repetição de valores supostamente pagos a maior ou indevidamente cobrados em se tratando de serviços não contratados de telefonia fixa advindos da alteração do plano de franquia / plano de serviços sem a solicitação do usuário - se decenal (artigo 205 do Código Civil), trienal (artigo 206, §3º IV, do Código Civil) ou outro prazo". Enquanto persistirem, porém, as incompreensões acima assinaladas, não é difícil prever em qual direção tenderão as decisões da Corte. Apenas a devida atenção quanto à fonte da obrigação de restituir permitirá alcançar conclusões tecnicamente precisas.

Idêntica controvérsia, aliás, já pacificada junto ao STJ, é a do prazo prescricional para a restituição do pagamento indevido de tarifas de água e esgoto feito às concessionárias desse serviço 31 V. Silva (2019) item 4.

32 Para um desenvolvimento do escopo contemporâneo da regra da subsidiariedade, v. Silva (2018a), item 2.4. 
público. A esse propósito, editou-se, em 2009, o verbete sumular n. 410, com a seguinte redação: “A ação de repetição de indébito de tarifas de água e esgoto sujeita-se ao prazo prescricional estabelecido no Código Civil". A despeito de não especificar de qual prazo se trata (simplesmente afastando a incidência de qualquer prazo previsto no Código de Defesa do Consumidor), a interpretação unânime conferida pelo STJ ao verbete é a de que se trataria do prazo geral decenal do art. 205 - como se extrai, aliás, da simples leitura dos acórdãos paradigmáticos que conduziram à edição do enunciado. Nestes, como se encontrava em discussão a aplicação de prazos prescricionais iniciados ainda sob a égide do Código Civil de 1916, fazia-se referência ao prazo geral vintenário, que era previsto pelo art. 177 da codificação anterior como prazo geral de prescrição. ${ }^{33}$

O fato de o enunciado sumular ter sido redigidojustamente a partir de acórdãos paradigmáticos em que se discutia a aplicação do Código Civil de 1916 prejudicou ainda mais a compreensão da questão, já que, sob a codificação anterior, não havia positivação da cláusula geral do enriquecimento sem causa e não estava previsto, por conseguinte, nenhum prazo prescricional específico para a pretensão restitutória. A constatação, porém, de o enunciado n. 410 ter sido deliberadamente editado para esclarecer que não se aplicava ao caso o prazo quinquenal do art. 27 do Código de Defesa do Consumidor (que trata de pretensão inegavelmente indenizatória) ${ }^{34}$ já oferece, por si só, uma evidência de que a confusão quanto à qualificação do dever de restituir já se encontrava instaurada na práxis, havendo aparente dúvida, desde então, quanto à fonte daquela obrigação. ${ }^{35}$

A edição do enunciado sumular nessas circunstâncias resulta, até os dias atuais, na aplicação do prazo prescricional decenal à pretensão da repetição do pagamento indevido de tarifas de água e esgoto, de natureza claramente restitutória, mesmo nos casos em que se encontra em discussão apenas a prescrição já iniciada sob a égide do Código Civil atual. ${ }^{36}$ Mais ainda, a aplicação do prazo geral da prescrição pelo STJ neste caso comprova a crença de que as pretensões de repetição do indébito decorrentes de pagamentos indevidos (um dos casos em que, como se afirmou anteriormente, optou o legislador por criar uma previsão específica para o dever de restituir) seriam uma hipótese autônoma, não filiada a nenhuma das fontes obrigacionais gerais.

A multiplicidade dos exemplos, a demonstrar a relevância do tema, coincide com a própria vastidão do fenômeno restitutório. Para além da definição do prazo prescricional da pretensão

33 Ilustrativamente: “A prescrição da ação para cobrança de preços públicos rege-se pelo art. 177, caput, do Código Civil de 1916, sendo portanto vintenária" (STJ, REsp 149.654/SP, $2^{\mathrm{a}}$ T., Rel. Min. Francisco Peçanha Martins, julg. 6.9.2005, publ. 17.10.2005). No mesmo sentido: STJ, EREsp 690.609/RS, $1^{\mathrm{a}}$ S., Rel. Min. Eliana Calmon, julg. 26.3.2008, publ. 7.4.2008; STJ, REsp 1.113.403/RJ, 1 a S, Rel. Min. Teori Zavascki, julg. 9.9.2009, publ. 15.9.2009.

34 In verbis: "CDC. Art. 27. Prescreve em cinco anos a pretensão à reparação pelos danos causados por fato do produto ou do serviço prevista na Seção II deste Capítulo, iniciando-se a contagem do prazo a partir do conhecimento do dano e de sua autoria".

35 Veja-se, por exemplo, o seguinte trecho do voto do relator no já mencionado REsp 1.113.403/RJ, um dos paradigmas para a edição do enunciado sumular: "Ora, o que se tem presente no caso é uma pretensão de restituir tarifa de serviço paga indevidamente. Não se trata, pois, de ação de reparação de danos causados por defeitos na prestação de serviços. Não há como aplicar à hipótese, portanto, o prazo do referido art. 27 do CDC. Também não se pode supor aplicável o prazo quinquenal estabelecido no Código Tributário Nacional - CTN, para restituição de créditos tributários, eis que a tarifa (ou preço) não tem natureza tributária. Quanto a esse aspecto, há mais de um precedente da própria Seção (EREsp n. 690.609, Min. Eliana Calmon, DJ 7.4.2008; REsp n. 928.267, Min. Teori Albino Zavascki, DJ de 21.8.2009). Não havendo norma específica a reger a hipótese, aplica-se o prazo prescricional estabelecido pela regra geral do Código Civil, ou seja: de 20 anos, previsto no art. 177 do Código Civil de 1916 ou de 10 anos, previsto no art. 205 do Código Civil de 2002."

36 Ilustrativamente: STJ, AREsp 1.481.962/RJ, 2a T., Rel. Min. Herman Benjamin, julg. 17.9.2019, publ. 11.10.2019; STJ, AgInt no REsp 1.587.925/RS, $1^{\text {a }}$ T., Rel. Min. Napoleão Nunes Maia Filho, julg. 29.4.2019, publ. 10.5.2019. 
restitutória daquele que houver efetuado pagamento indevido (art. 876 do Código Civil), seria possível, igualmente, questionar: qual é o prazo prescricional da pretensão do gestor de negócios alheios à restituição das despesas necessárias ou úteis na hipótese de a gestão ser reputada útil ao dono (art. 869)? Ou, ainda: qual é o prazo prescricional da pretensão do possuidor à restituição das benfeitorias por parte do proprietário (arts. 1.219 e 1.220)? E assim por diante. Dentre tantos exemplos possíveis, chega-se, neste ponto da exposição, a dois casos bastante particulares de restituição (nomeadamente, os deveres de restituir resultantes da declaração de nulidade contratual e da resolução contratual), cujo tratamento pela jurisprudência pátria mostra-se igualmente problemático. É o que se passa a comentar.

\section{UM EXEMPLO PARADIGMÁTICO DA INCOMPREENSÃO: O PRAZO PRESCRICIONAL APLICÁVEL À PRETENSÃO RESTITUTÓRIA DECORRENTE DA RESOLUÇÃO CONTRATUAL}

Dentre todas as hipóteses ilustrativas do problema acima relatado, atinente à incompreensão jurisprudencial sobre fonte obrigacional restitutória, um recente julgado, também de lavra do Superior Tribunal de Justiça, desperta a atenção por utilizar, em sua fundamentação, duas hipóteses igualmente representativas do dever de restituir, atribuindo-lhes, porém, qualificações diversas. Curiosamente, a ratio decidendi adotada nessa ocasião fundou-se expressamente em um julgamento anterior, no qual se havia conferido a qualificação correta à pretensão restitutória que se encontrava em discussão. Vale dizer: do acerto anterior derivou-se um novo julgamento, lamentavelmente atécnico. Seguindose a ordem cronológica dos julgamentos, narram-se, a seguir, primeiramente o caso que traduziu em grande acerto de nossa jurisprudência e, em seguida, aquele que culminou na perpetuação do já referido cenário de incompreensão.

No ano de 2016, o Superior Tribunal de Justiça pacificou uma controvérsia até então bastante frequente no âmbito de contratos de promessa de compra e venda de imóveis, consistente na validade ou não das cláusulas contratuais que impunham ao adquirente o dever de arcar com o pagamento de comissão de corretagem e da chamada taxa SATI (serviços de assessoria técnica-imobiliária). A questão, consolidada no Tema Repetitivo n. 938, acarretava uma segunda indagação, já conhecida a este ponto do presente estudo: qual seria o prazo prescricional para requerer a restituição dos valores pagos a título de comissão de corretagem e de taxa SATI, nos casos em que as cláusulas contratuais que as estipulavam fossem reputadas nulas? Em julgamento notável pela precisão técnica, definiu a Corte que o prazo aplicável à pretensão de restituição é o de três anos, nos termos do art. $206, \S 3^{\circ}$, IV, do Código Civil, por se reconhecer que a pretensão filia-se ao campo do enriquecimento sem causa. ${ }^{37}$

37 Assim restou consignado no julgamento de um dos recursos paradigmáticos que se encontravam afetados ao tema (STJ, REsp 1.551.956/SP, $3^{\mathrm{a}}$ T., Rel. Min. Paulo de Tarso Sanseverino, julg. 24.8.2016, publ. 6.9.2016). Na ocasião, prevaleceu o entendimento que havia sido firmado pouco antes pela Segunda Seção, no julgamento do REsp 1.360.969/RS, de relatoria do Min. Marco Buzzi, que versava sobre outra discussão (nulidade de cláusulas de reajuste em contratos de plano de saúde). Neste último julgamento, que se deu por maioria, o relator restou vencido, tendo sido designado para lavrar o acórdão o Min. Marco Aurélio Bellizze, que sustentou a tese vencedora da aplicabilidade do prazo trienal. Ao apreciar a questão da abusividade da cobrança da comissão de corretagem e da taxa SATI, embora tenham ressalvado entendimentos pessoais quanto à aplicabilidade do prazo geral decenal, os julgadores da Terceira Turma optaram por prestigiar o entendimento que acabara de ser expresso pela Segunda Seção, tendo, por isso, prevalecido a tese do prazo trienal. 
Com efeito, declarada nula uma disposição contratual, a transferência patrimonial que havia sido feita em observância àquela cláusula perde seu título justificativo, de modo que a restituição da prestação se torna imperativa, sob pena de enriquecimento injusto do credor que a recebeu. A esse respeito, importa a análise do art. 182 do Código Civil, que, ao prever a retroatividade da invalidação do negócio jurídico, determina que, não sendo possível restituir as partes ao estado anterior, serão as mesmas "indenizadas com o equivalente". ${ }^{38} \mathrm{O}$ dispositivo mostra-se impreciso ao fazer alusão à ideia de "indenização"39 - quando, em verdade, está prevendo uma obrigação legal de restituição de prestações já realizadas, a qual decorre da vedação ao enriquecimento sem causa. ${ }^{40}$ Nos ordenamentos, como o italiano, em que não há comando legal expresso determinando a restituição, a associação desta à vedação ao enriquecimento sem causa se revela mais imediata e não desperta grande dissenso doutrinário. ${ }^{41}$ Por outro lado, em outros sistemas, como o português, parte da doutrina oscila na qualificação - muito embora isso decorra de aspectos particulares da disciplina legal das invalidades negociais e da restituição do enriquecimento sem causa, e não da lógica geral que guia o dever de restituição. ${ }^{42}$

38 No ponto, ulteriores considerações podem ser encontradas em Souza ( 2017a, p. 245-247).

39 Assim como ocorre, em geral, na responsabilidade civil, a restituição de valores caso o contrato seja declarado nulo visa ao retorno das partes in statu quo ante; contudo, essa restituição pode ou não ser cumulada com perdas e danos, assim como pode acontecer de nada precisar ser restituído, caso não tenha havido qualquer início de execução para o negócio. A respeito, leciona Menezes Cordeiro: “deve ser restituído tudo o que tiver sido prestado, ou, se a restituição em espécie não for possível, o valor correspondente, nos termos desse mesmo preceito. [...] O dever de restituir é recíproco. A doutrina estrangeira já intentou, por via doutrinária, construir aqui um sinalagma, de modo a permitir a aplicação de institutos que garantam as posições das partes. A lei portuguesa solucionou, de modo expresso, o problema, no artigo $290^{\circ}$ : 'As obrigações recíprocas de restituição que incumbem às partes, por força da nulidade ou anulação do negócio devem ser cumpridas simultaneamente, sendo extensivas ao caso, na parte aplicável, as normas relativas à exceção do contrato não cumprido'. [...] A nulidade ou a anulação de um negócio são, ainda, suscetíveis de causar danos ilícitos. Podem intervir institutos de responsabilidade civil e, designadamente, a culpa in contrahendo" (CORDEIRO, 2012, p. 936-938).

40 A respeito, leciona-se que, "desfeito o vínculo contratual, nenhuma pretensão poderá mais, obviamente, ser fundada sobre ele. Mais delicado é o discurso no caso em que o contrato já tenha tido execução parcial; nos casos desse gênero ingressam os remédios restitutórios, com a finalidade de permitir a recuperação do que foi prestado sem causa, a prescindir de esclarecimentos acerca da imputabilidade ou não do inadimplemento" (GALLO, 2008, p. 1075. Tradução livre).

41 Nesse sentido, v. Bianca (2000, p. 631), Alpa (2006, p. 132), Gazzoni (2015, p. 1000). Nesses ordenamentos, a questão mais debatida costuma ser a da proximidade ou distanciamento do regime da restituição em relação à disciplina legal do pagamento indevido. De fato, ao tratar da peculiaridade dos sistemas da família romano-germânica na matéria, explica Paolo Gallo que sistemas como o francês e o italiano adotaram, em linhas gerais, um modelo unitário do dever de restituir, ao passo que o sistema alemão segue um modelo binário, que trata diferentemente as restituições que decorrem do desfazimento contratual. No entanto, observa o autor, "em tempos recentes se tem observado fortes tendências de se diversificar o regime restitutório mesmo em ordenamentos como o francês e o italiano, tradicionalmente inspirados pela ideia da unidade da condictio. [...] Não se quer que a ausência de erro [elemento caracterizador do pagamento indevido] iniba o exercício da ação de nulidade, também para evitar que a execução consciente do contrato possa explicar um efeito sanatório" (GALLO, 2008, p. 1076-1077. Tradução livre). Na França, onde o enriquecimento sem causa foi desenvolvido pelo trabalho jurisprudencial, afirma-se que "a destruição do passado (o retorno ao statu quo ante) levanta sempre mais dificuldades que o desenvolvimento das situações adquiridas (a execução do contrato). A restituição lembra um pouco a repetição do indébito (art. 1376 [do Code Napoléon]), mas a condição de erro não é exigida" (MALAURIE; AYNĖS; STOFFEL-MUNCK, 2015, p. 358).

42 Embora pondere que "o enriquecimento sem causa seria a via natural para, perante a invalidação de um negócio, fazer reverter quanto houvesse sido prestado", mencionando ser esta, por exemplo, a solução adotada no direito alemão, Menezes Cordeiro acaba concluindo que, no direito lusitano, a obrigação de restituir decorrente da invalidade negocial seria autônoma em relação ao princípio; leva em conta, para tanto, distinções entre essa obrigação de restituição e aquela decorrente, em específico, do pagamento indevido (tais como natureza da sentença, prazo para exercício etc.), que, em princípio, não se aplicam ao direito brasileiro (CORDEIRO, 2010, t. 3, p. 261-262). Particularmente quanto ao prazo, muitos autores diferenciam a decadência da declaração de nulidade e a prescrição da pretensão de restituição, associando esta última à vedação ao enriquecimento sem causa. Além disso, mesmo no direito português, alguns autores reconhecem a influência do princípio de vedação ao enriquecimento sem causa sobre o dever de restituição decorrente da invalidade negocial. Nesse sentido, afirma Júlio Gomes: "consideramos tratar-se aqui de uma restituição de prestações fundada num enriquecimento sem causa, mas em que não é necessária uma ação autônoma de enriquecimento sem causa" (GOMES, 1998, p. 609-610). O dissídio doutrinário, destaca o autor, decorre do fato de se conceber "a obrigação de restituição fundada no enriquecimento sem causa, como visando, exclusivamente, o enriquecimento patrimonial", o que não permite explicar a disciplina prevista pelo art. $289^{\circ}$, I do Código Civil português para as consequências da nulidade: "no intercâmbio de prestações, resultante da execução de um contrato sinalagmático, apenas uma das partes, quando 
Nesse sentido, e sem embargo de tais divergências, parece inegável que a vedação ao enriquecimento sem causa desempenha um papel fundamental na disciplina da invalidade negocial, ${ }^{43}$ previsto pelo dispositivo: o desfazimento do negócio por força do reconhecimento da nulidade ou da anulação do contrato determina para as partes o dever de restituição de prestações eventualmente já executadas sob pena de, em caso contrário, restar verificado um enriquecimento injusto. ${ }^{44} \mathrm{~A}$ rigor, por decorrer a invalidade (do inteiro negócio ou de apenas uma de suas cláusulas - o que se denomina invalidade parcial) de um vício originário do negócio, ${ }^{45}$ seria possível afirmar que, formalmente, sempre faltou um título justificativo à transferência patrimonial feita em cumprimento do acordo de vontades (ou que, ao menos, esse título sempre esteve maculado pelo vício). De todo modo, ainda que se compreenda que o título jurídico apenas deixou de existir após a declaração de nulidade contratual, a conclusão seria a mesma: a restituição das prestações feitas em cumprimento do negócio ainda seria regida pelas regras referentes ao enriquecimento sem causa, tendo em vista o disposto pelo art. 885 do Código Civil, segundo o qual "a restituição é devida, não só quando não tenha havido causa que justifique o enriquecimento, mas também se esta deixou de existir". Resta evidente, assim, o acerto do entendimento adotado pelo STJ neste primeiro caso.

Pouco tempo depois, em 2019, novamente foi o Superior Tribunal de Justiça instado a se pronunciar sobre o prazo prescricional aplicável a uma nova pretensão restitutória. Desta vez, a controvérsia de fundo, cada vez mais frequente no direito brasileiro, consistiu na resolução de um contrato de compra e venda de imóvel na planta em decorrência do inadimplemento da construtora com o andamento do empreendimento. Mais especificamente, debatia-se, no REsp 1.737.992/RO, ${ }^{46}$ qual seria o prazo prescricional aplicável à restituição das parcelas do preço do imóvel que já haviam sido pagas pelo adquirente até o momento da resolução. Afirmando a perda do interesse útil na entrega do imóvel em decorrência da prolongada mora da construtora, o comprador pretendia a extinção do negócio, nos termos do art. 475 do Código Civil, e, consequentemente, pugnava pelo retorno das partes in statu quo ante, com a restituição das parcelas que ele havia pago e que, com a resolução da avença, perderam seu título jurídico justificador. Surgiu, assim, a dúvida sobre o prazo prescricional incidente sobre a sua pretensão.

Surpreendentemente, a conclusão alcançada pelo STJ foi a de que deveria ser mantido o acórdão do Tribunal Estadual de origem, que aplicara à pretensão restitutória o prazo geral decenal de prescrição (art. 205 do Código Civil). ${ }^{47}$ Como a hipótese controvertida tratava de uma aquisição

muito, poderia considerar-se enriquecida, em razão de ter recebido uma prestação de valor superior ao que dispendeu, pelo que apenas a ela caberia uma obrigação de restituição dirigida, tão-só, a essa diferença de valor" (GOMES, 1998, p. 611-612). O autor resolve a questão ao demonstrar como, a depender da natureza das prestações decorrentes do contrato inválido, as consequências impostas pela vedação ao enriquecimento sem causa serão distintas; assim, por exemplo, na compra e venda declarada nula ao poder de reivindicação da coisa pelo proprietário legítimo não corresponde um poder de reivindicação do preço pela parte prejudicada, eis que o dinheiro não se sujeita a esse tipo de ação, devendo sua restituição ocorrer no âmbito de uma ação fundada no enriquecimento.

43 Sobre a relevância da vedação ao enriquecimento sem causa na modulação das consequências da invalidade negocial, v. Souza (2017a), item 3.4.

44 Sobre a noção de enriquecimento injusto como uma perspectiva funcionalizada do dever de restituição à luz dos valores do ordenamento, v. Silva (2018), item 2.3.2.

45 Já que não se reconhece a possibilidade de existirem causas supervenientes de nulidade, como se pôde analisar em Souza (2017b, p. 12-13).

46 STJ, REsp 1.737.992/RO, 3ª T., Rel. Min. Paulo de Tarso Sanseverino, julg. 20.8.2019, publ. 23.8.2019.

47 O acórdão recebeu a seguinte ementa: "Recurso especial. Civil e processual civil. CPC/2015. Promessa de compra 
imobiliária (mesma espécie contratual de que tratava o Tema Repetitivo n. 938, acima comentado), a comparação com o prazo prescricional trienal que se considera aplicável à restituição da comissão de corretagem abusiva e da taxa SATI foi inevitável. No entanto, entenderam os julgadores que a tese favorável à aplicação do prazo trienal "foi firmada no âmbito de demandas cuja causa de pedir era a abusividade da transferência desses custos ao consumidor", ao passo que, no caso ora sob apreciação, a controvérsia dizia respeito "à aplicação dessa tese a uma demanda cuja causa de pedir é o inadimplemento contratual por parte da incorporadora". ${ }^{48}$ Em outros termos, sustentaram que haveria uma diferença fundamental de regime jurídico entre a restituição decorrente de declaração de nulidade de cláusula contratual e aquela motivada pela resolução contratual decorrente do inadimplemento.

No que diz respeito à fonte obrigacional, contudo, não há, a rigor, nenhuma diferença entre a restituição de valores pagos em cumprimento de uma cláusula contratual nula e a restituição de valores pagos em cumprimento de um contrato que veio a ser resolvido. ${ }^{49} \mathrm{O}$ ordenamento brasileiro poderia, por certo, ter seguido a experiência legislativa de alguns países da tradição romano-germânica, no sentido de positivar uma previsão genérica acerca da aptidão da resolução contratual para deflagrar as obrigações restitutórias a cargo de ambos os contratantes. Assim sucede, por exemplo, nas codificações italiana, portuguesa e francesa. O chamado "efeito restitutório da resolução", ${ }^{50}$ porém, ao contrário da restituição decorrente da declaração de nulidade do contrato (que conta com referência expressa do art. 182 do Código Civil), não costuma ser acompanhado de maior fundamentação sobre sua origem ou justificativa no direito brasileiro, ${ }^{51}$ o que parece dificultar a compreensão sobre a fonte do dever de restituir.

e venda. Incorporação imobiliária. Atraso na entrega do imóvel. Pretensão de restituição de parcelas pagas, comissão de corretagem e SATI. Prescrição. Inocorrência. Necessidade de pronunciamento judicial sobre a resolução judicial do contrato no caso. Distinção com a hipótese de prescrição trienal do tema 938/STJ. Danos materiais. Ausência indicação da questão federal. Óbice da súmula 284/STF. 1 . Controvérsia acerca da prescrição das pretensões restituitorias decorrentes da resolução de promessa de compra e venda por atraso na entrega do imóvel. 2. Nos termos da Súmula 543/STJ: 'Na hipótese de resolução de contrato de promessa de compra e venda de imóvel submetido ao Código de Defesa do Consumidor, deve ocorrer a imediata restituição das parcelas pagas pelo promitente comprador - integralmente, em caso de culpa exclusiva do promitente vendedor/construtor, ou parcialmente, caso tenha sido o comprador quem deu causa ao desfazimento'. 3. Caso concreto em que a resolução foi pleiteada com base na culpa da incorporadora, sendo cabível, portanto, a restituição integral das parcelas pagas, nos termos da referida súmula. 4. No julgamento do Tema 938/STJ, esta Corte Superior concluiu pela Incidência da 'prescrição trienal sobre a pretensão de restituição dos valores pagos a título de comissão de corretagem ou de serviço de assistência técnico-imobiliária (SATI), ou atividade congênere (art. 206, § $3^{\circ}$, IV, CC)'. 5. Distinção entre a pretensão restituitória abordada no Tema 938/STJ (fundada na abusividade de cláusula contratual) e a pretensão restituitória do caso dos autos (fundada na resolução do contrato por inadimplemento da incorporadora). Doutrina sobre o tema da pretensão restituitória decorrente da resolução do contrato. 6. Inaplicabilidade do Tema 938/STJ aos casos em que a pretensão de restituição da comissão de corretagem e da SATI tem por fundamento a resolução do contrato por culpa da incorporadora. 7. Recurso especial desprovido, com majoração de honorários".

48 Trechos do voto do relator.

49 Assim já se pôde sustentar em Souza (2017a), item 3.4; Silva (2018b, passim) e Silva (2018a), item 3.2.

50 Para um desenvolvimento da análise dos "efeitos da resolução" (quais sejam, o liberatório, o reparatório e o restitutório), com particular destaque para o denominado efeito restitutório, v. Silva (2019), itens 2 e 3.

51 Nesse sentido, v. Michelon Junior (2007, p. 252). Semelhante conclusão é alcançada pela doutrina italiana: “A correlação entre a caducidade dos efeitos do contrato e a obrigação de restituição da prestação parece indubitável, até mesmo banal na sua obviedade, mas constitui ainda no nosso sistema inocente um dos pontos mais tormentosos da matéria do pagamento indevido e da teoria do contrato" (MOSCATI, 2012, p. 198, tradução livre). Uma possível razão para a parca atenção usualmente dispensada à fundamentação do denominado efeito restitutório da resolução talvez seja a tendência da sua

consagração desde o direito romano: "O direito romano deu aos contratos inominados uma dupla sanção: de uma parte, uma ação em execução; de outra parte, uma condictio na repetição da prestação cumprida, condictio que era apenas uma aplicação dos princípios romanos do enriquecimento injusto: o contratante poderia retomar sua coisa quando não houvesse obtido a contraprestação, causa data causa non secuta" (MAZEAUD; MAZEAUD; MAZEAUD, 1985, p. 1.120 , tradução livre). 
Ilustrativamente, o artigo 1.458 do Codice Civile italiano ${ }^{52}$ estabelece o "efeito retroativo" ("effetto retroattivo") da resolução do contrato por inadimplemento - previsão essa interpretada no sentido da consagração do efeito restitutório da resolução $-{ }_{,}^{53}$ ressalvada a irretroatividade a propósito das prestações já cumpridas. ${ }^{54}$ No direito português, o artigo 433 do Código Civil ${ }^{55}$ equipara os efeitos da resolução aos da invalidade do negócio jurídico, ${ }^{56}$ ao passo que o artigo $434{ }^{57}$ prevê o "efeito retroactivo" da resolução, com as ressalvas indicadas no dispositivo. ${ }^{58}$ Por sua vez, o artigo 1.229 do Code civil francês (com a redação determinada pela Ordonnance du 10 février 2016) ${ }^{59}$ disciplina minuciosamente a restituição decorrente da resolução, ${ }^{60}$ determinando a irretroatividade

52 In verbis: "Art. 1.458. A resolução do contrato por inadimplemento tem efeito retroativo entre as partes, salvo o caso de contratos de execução continuada ou periódica, em relação aos quais o efeito da resolução não se estende às prestações já cumpridas. [...].”.

53 Afirma-se, a propósito da consagração do efeito restitutório da resolução: "Fala-se, então, de efeitos liberatórios ex nunc em relação às prestações ainda não cumpridas e de efeitos restitutórios ex tunc a propósito da necessidade de devolver o quanto recebido em execução do contrato resolvido" (SICCHIERO, 2007, p. 672. Tradução livre). Para uma crítica à tese da retroatividade plena dos efeitos da resolução, v. Argiroffi $(1984$, p. 61 e ss.). Também em perspectiva crítica, a diferenciar o que denomina "doutrina da retroatividade em sentido fraco" ("dottrina della retroattività in senso debole"), "doutrina da retroatividade em sentido forte" ("dottrina della retroattività in senso forte") e "doutrina da irretroatividade" ("dottrina della irretroattività), v. Belfiore (1988, p. 246-267).

54 Afirma-se, a propósito: "O limite de caráter objetivo diz respeito aos contratos de execução continuada ou periódica em que, como já se disse, o efeito da resolução não estende às prestações já cumpridas (art. $\left.1.458 \mathrm{n}^{\circ} 1\right)$. A norma [...] se funda sobre o pressuposto de que nos contratos de execução continuada ou periódica as prestações se encontram em uma relação de correspectividade a coppie e que, portanto, seja do ponto de vista econômico ou daquele jurídico, podem ser consideradas separadamente tanto das prestações precedentes quanto daquelas sucessivas. A retroatividade operará, portanto, apenas nos limites em que a correspectividade subsiste e, então, se uma prestação não seja proporcional à outra, deverá ter lugar igualmente uma restituição parcial" (CARRESI, 1997, p. 912. Tradução livre).

55 In verbis: "Artigo $433^{\circ}$ (Efeitos entre as partes). Na falta de disposição especial, a resolução é equiparada, quanto aos seus efeitos, à nulidade ou anulabilidade do negócio jurídico, com ressalva do disposto nos artigos seguintes".

56 A propósito, afirma-se: "A faculdade de exigir a restituição do que já tiver sido prestado deve ser aproximada da eficácia retroactiva da resolução - artigo $434^{\circ}$. A restituição tem a natureza da prevista para a invalidação $\left(433^{\circ}\right.$ e $\left.289^{\circ}\right)$ " (CORDEIRO, 2010, t.4, p. 139).

57 In verbis: "Artigo $434^{\circ}$ (Retroactividade). 1. A resolução tem efeito retroactivo, salvo se a retroatividade contrariar a vontade das partes ou a finalidade da resolução. Nos contratos de execução continuada ou periódica, a resolução não abrange as prestações já efectuadas, excepto se entre estas e a causa de resolução existir um vínculo que legitime a resolução de todas elas".

58 "A resolução do contrato determina igualmente a restituição das prestações realizadas em execução do contrato. Justamente por isso o legislador equipara o seu regime ao da invalidade do negócio jurídico (art. 433), sendo-lhe em consequência aplicável também o art. 289. Estabelecem-se apenas as restrições de que a resolução não tem efeito retroactivo se essa retroactividade contrariar a vontade das partes ou a finalidade da resolução (art. $434, n^{\circ} 1$ ), de que nos contratos de execução continuada ou periódica não abrange as prestações já realizadas, excepto se entre estas e a causa de resolução existir um vínculo que legitime a resolução de todas elas (art. 434, $n^{\circ} 2$ ) e de que não prejudica os direitos adquiridos por terceiro, excepto se o contrato respeitar a bens registráveis e o registro da acção de resolução preceder o desses direitos (art. 435). Esta última restrição veda, em princípio, a aplicação à resolução do contrato do regime do art. 289, n 2" (LEITÃO, 1996, p. 470). Do mesmo autor, v., ainda, Leitão (2010, p. 271 e ss.)

59 In verbis: "Art. 1229. Quando as prestações trocadas não puderem atingir a sua utilidade sem a execução completa do contrato resolvido, as partes devem restituir a integralidade daquilo que tiverem entregado uma à outra. Quando as prestações trocadas tiverem atingido a sua utilidade do modo e na medida da execução recíproca do contrato, não tem lugar a restituição para o período anterior à última prestação que não recebeu a sua contrapartida; nesse caso, a resolução é qualificada como resilição [...]" (Tradução livre). A tradução de "résiliation" para "resilição" poderia surpreender, uma vez que ambos os remédios previstos pelo legislador francês no dispositivo mencionado (résolution e résiliation) prestam-se a tutelar uma situação de inadimplemento contratual, ao passo que a civilística brasileira reserva a expressão "resilição" para a extinção voluntária do contrato (cf. TEPEDINO; SCHREIBER; FRADERA, 2005, p. 695). À luz de tais considerações, o possível equívoco aventado, se realmente existente, parece residir não na tradução de "résiliation" para "resilição", mas sim na opção do legislador francês em diferenciar as hipóteses de extinção do vínculo contratual em razão do inadimplemento (unitariamente designadas em português pela expressão "resolução") conforme os efeitos da extinção sejam retroativos (hipótese da "résolution") ou irretroativos (hipótese da "résiliation"). Precisamente nesse sentido, a criticar a opção do legislador francês que veio a restar consagrada na reforma de 2016, afirma-se, na doutrina francesa: "Há muito tempo, tomou-se o hábito de dizer que a resolução por inexecução, em princípio retroativa, não é assim quando afeta um contrato de execução sucessiva e que, sendo válida apenas para o futuro, ela muda de nome e é chamada de 'resilição' [résiliation]. Na realidade, esta apresentação é errônea, incompleta e largamente desmentida pela jurisprudência moderna"

(GENICON, 2015, p. 1.605, tradução livre). O autor arremata: "Em suma, a palavra resilição não diz nada sobre os efeitos (não retroativos) da aniquilação de um contrato, mas fala apenas da causa desse aniquilamento" (GENICON, 2015, p. 1.606, tradução livre). No mesmo sentido da crítica, v., ainda na doutrina francesa, Larroumet e Bros (2016, p. 806-807).

60 Para uma análise do histórico legislativo que veio a conduzir à reforma promovida pelo Ordonnance du 10 février 2016 
ou retroatividade desta conforme, respectivamente, o adimplemento parcial tenha ou não produzido resultado útil para os contratantes. ${ }^{61}$

A referida solução francesa - semelhante, nesse ponto, à italiana - parece seguir certa tendência doutrinária no sentido da irretroatividade da resolução (notadamente do seu efeito restitutório) no âmbito de contratos com obrigações de trato sucessivo, ${ }^{62}$ reconhecendo-se que as prestações e contraprestações regularmente adimplidas antes da situação do inadimplemento encontrariam causa legítima no contrato então vigente. ${ }^{63}$ A restituição haveria de se limitar, por conseguinte, às prestações pagas sem o devido correspectivo, o que se verifica após a configuração do inadimplemento. ${ }^{64}$ Assevera-se, nesse sentido, que " $(\mathrm{O})$ efeito da resolução entre as partes varia, pois, conforme o contrato seja de execução única ou de duração. No primeiro caso a resolução opera ex tunc, no segundo, ex nunc" (GOMES, 2007, p. 210).

Ao contrário do que ocorreu nos ordenamentos acima mencionados, a positivação expressa do efeito restitutório (por vezes denominado simplesmente retroativo) da resolução não foi o caminho trilhado pela codificação brasileira. ${ }^{65}$ A obrigação de restituição, nesse cenário, apenas pode se vincular, no quadro geral de fontes das obrigações no direito brasileiro, à cláusula geral de vedação ao enriquecimento sem causa, remontando diretamente à hipótese de ausência superveniente de causa de que trata o artigo 885 do Código Civil. ${ }^{66}$ De fato, ao desfazer o vínculo contratual, a resolução suprime a fonte que justificava as transferências patrimoniais, as quais deverão, em regra, ser integralmente restituídas a fim de se reprimir a configuração de enriquecimento sem causa. ${ }^{67}$ $\mathrm{O}$ reconhecimento do efeito restitutório à míngua de previsão legal específica parece traduzir, em suma, decorrência direta da cláusula geral do dever de restituir contida no artigo 884 do Código Civil, na feição própria de ausência superveniente de causa (artigo 885 do Código Civil). ${ }^{68}$

especificamente na matéria da resolução contratual, v. Boucard (2015, p. 165-166).

61 A propósito, v., por todos, Simler (2016, p. 46) e Benabent (2016, p. 301).

62 A regra, positivada pela reforma francesa de 2016, consagrou substancialmente o entendimento então já prevalente em sede doutrinária. A propósito, v., por todos, Mazeaud, Mazeaud e Mazeaud (1985, p. 1.129) e Terré, Simler e Lequette (2013, p. 707-708).

63 "O efeito específico da resolução é extinguir o contrato retroativamente. Opera ex tunc. Esse efeito corresponde à intenção presumida das partes. Extinto o contrato pela resolução, apaga-se o que se executou, devendo-se proceder a restituições recíprocas, se couberem. Contudo, só é possível remontar à situação anterior à celebração do contrato se este não for de trato sucessivo, pois, do contrário, a resolução não tem efeito em relação ao passado; as prestações cumpridas não se restituem" (GOMES, 2007, p. 210).

64 "Feita exceção para os contratos de duração, a resolução tem efeito retroativo entre as partes, que são obrigadas a restituir as prestações recebidas" (ROPPO, 2006, p. 379, tradução livre).

65 Tal omissão se verificava já no Projeto de Código Civil, conforme ressaltado por Ruy Rosado de Aguiar Júnior: "Nada disse [o Projeto de Código Civil] sobre a necessidade de serem as partes restituídas à situação anterior, com devolução das quantias pagas e indenização pelos danos sofridos pelo adimplente, e os casos em que isso ocorre" (AGUIAR JÚNIOR, 2000, p. 27).

66 Nesse sentido, v. Silva (2018a), item 3.3.1. A vinculação do denominado efeito restitutório da resolução à disciplina da vedação ao enriquecimento sem causa, porém, encontra opositores na doutrina estrangeira. Para uma análise do tema, com especial destaque à relação entre a restituição e a indenização correspondente ao interesse negativo, v. Pinto (2008, p. 969 e ss.) e Pardolesi (2007, p. 493 e ss.)

67 Ao propósito, a identificar uma função restitutória da obrigação de restituição deflagrada pela resolução contratual, v., na doutrina italiana, D'Adda, 2000, p. 536. Em sentido semelhante, ainda que sem vincular expressamente o efeito restitutório à vedação ao enriquecimento sem causa, reconhece-se a eliminação da causa justificadora da atribuição patrimonial: "A resolução elimina a causa justificadora das prestações contratuais e, portanto, obriga a restituir aquilo que se tenha recebido em execução do contrato" (TRIMARCHI, 2010, p. 72, tradução livre).

68 Semelhante conclusão é alcançada no âmbito da doutrina italiana ao se justificar o reconhecimento do efeito restitutório a partir da exegese do artigo 1.458 do Codice Civile: "Coerentemente com o implemento do nosso código e com a vedação ao enriquecimento sem causa, de fato, o rompimento do vínculo, em vez de operar apenas a partir do momento em que se verifica, elimina retroativamente toda modificação produzida pelo acordo, correspondendo, assim, a norma ao comum sentimento das pessoas, já que quem não teve aquilo lhe compete pretende a restituição daquilo que tenha 
Essas premissas, desconsideradas no julgamento do mencionado REsp 1.737.992/RO, resultaram, mais uma vez, na malfadada aplicação de prazos prescricionais distintos a pretensões caracterizadas por idêntica função. Não havia, como se percebe, razão idônea a justificar o discrímen a partir do qual a Corte concluiu pelo afastamento do prazo prescricional trienal dispensado às pretensões de restituição do enriquecimento sem causa. Mais adequado teria sido, portanto, a aplicação do prazo prescricional trienal do art. 206, $\S 3^{\circ}$, IV, do Código Civil à generalidade das pretensões restitutórias, independentemente de terem fonte na cláusula geral do art. 884 do Código Civil ou em outras hipóteses específicas. ${ }^{69}$

Mais do que isso, o acórdão proferido nesse julgamento ainda incorreu em outras confusões de ordem teórica. Argumentaram os julgadores, na ocasião, que, consistindo o direito à resolução em um direito potestativo, não se poderia aplicar ao caso o entendimento aplicado no julgamento do Tema Repetitivo n. 938 (comissão de corretagem e taxa SATI), pois aos direitos potestativos se aplica a decadência e não a prescrição. ${ }^{70} \mathrm{O}$ argumento é manifestamente improcedente, ao menos por duas ordens de razão. A uma, por ser certo que também o direito a obter a declaração de nulidade (total ou parcial) do contrato é potestativo, ${ }^{71}$ o que faz cair por terra a pretendida diferenciação. A duas, porque o direito à restituição de valores pagos (decorrente, como se viu, tanto do exercício do direito potestativo à declaração de nulidade quanto do direito potestativo à resolução) consiste em direito autônomo face ao direito extintivo. A natureza do direito à restituição é a de simples direito subjetivo de crédito, como ocorre nos variados casos de restituição motivada pela vedação ao enriquecimento sem causa. À pretensão restitutória deflagrada pela resolução aplica-se, portanto, o instituto da prescrição.

\section{CONCLUSÃO}

A tripartição funcional das obrigações afigura-se, em alguma medida, uma solução possível para um problema que ela própria evidencia. Com efeito, não fosse a assunção da premissa metodológica acerca do reconhecimento das funções características das obrigações no direito civil, provavelmente não se ressentiria a comunidade jurídica do tratamento assistemático da restituição. Desse modo, em razão da suposta ausência de identidade entre as diversas hipóteses de restituição, sequer pareceria lógico dispensar-lhes tratamento em alguma medida unitário. Uma vez, contudo, que se reconheça a existência de um perfil funcional comum entre obrigações restitutórias as mais variadas - destinadas a remover um enriquecimento injustificado (excluídas, portanto, restituições que traduzam simples obrigação de dar coisa certa alheia em cumprimento de um negócio jurídico) -, a promoção de disciplina unitária exsurge como autêntica imposição de ordem metodológica.

dado" (SICCHIERO, 2007, p. 673, tradução livre). Também a doutrina francesa alcançava conclusão semelhante antes mesmo da positivação expressa do efeito restitutório pela reforma promovida no direito das obrigações em 2016: “[...] a resolução faz também desaparecer o contrato retroativamente. Há o retorno ao status quo ante, o que implica ausência de empobrecimento e de enriquecimento das partes" (TERRÉ; SIMLER; LEQUETTE, 2013, p. 705, tradução livre). Ao propósito, v. Silva (2018a, p. 284-285).

69 Ao propósito, v. Silva, 2018a, item 3.1.2.

70 "Tratando-se de um direito potestativo, não há falar em prazo de prescrição, mas em decadência, o que por si só já afastaria a aplicação do Tema 938/STJ ao caso" (Trecho do voto do relator).

71 V. Souza (2017a, p. 210). 
A dificuldade de enfrentamento sistemático das obrigações restitutórias parece remontar, nesse contexto, à resistência em se reconhecer o papel da vedação ao enriquecimento sem causa no quadro geral de fontes das obrigações civis. ${ }^{72}$ Verifica-se, como visto, uma recorrente confusão entre a fonte da vedação ao enriquecimento sem causa (a determinar a incidência de um regime geral para obrigações de perfil funcional restitutório) e a cláusula geral do dever de restituir (a fazer deflagrar a obrigação restitutória quando observados os pressupostos positivos e negativo previstos nos arts. 884 e 886, respectivamente). Transportam-se, assim, para o inteiro tratamento das obrigações restitutórias as cautelas tomadas a propósito da incidência direta da cláusula geral do dever de restituir, o que repercute, por exemplo, na usual compreensão de uma suposta subsidiariedade da fonte obrigacional da vedação ao enriquecimento sem causa, em nítida demonstração da confusão entre o instituto (fonte autônoma de obrigações) e a sua respectiva cláusula geral (essa, sim, subsidiária nos termos do art. 886 do Código Civil).

Tal cenário de confusão conceitual e tratamento assistemático das obrigações restitutórias prejudica, por evidente, a determinação do regime jurídico a elas aplicável. Essas sequelas podem ser ilustradas pelo problema da definição do prazo prescricional. Com grande frequência, diante de uma hipótese de restituição disciplinada por norma específica, indaga-se: deve ser aplicado o prazo geral de dez anos (art. 205) ou o prazo trienal específico da "pretensão de ressarcimento de enriquecimento sem causa" (art. 206, $\S 3^{\circ}$, inciso IV)? A verdadeira dúvida, porém, a confundir o julgador brasileiro ainda nos dias de hoje parece ser: devem ser vinculadas ao regime geral do enriquecimento sem causa as pretensões restitutórias que não decorram diretamente da cláusula geral do dever de restituir contida no art. 884 do Código Civil?

Uma vez mais, o reconhecimento da tripartição funcional das obrigações presta valioso auxílio. $\mathrm{O}$ fato de variadas obrigações guardarem em comum um mesmo perfil funcional aconselha, como já enunciado, a incidência de uma disciplina jurídica unitária. Não se trata de proclamar uma homogeneidade absoluta, mas tão somente um tratamento comum naquilo que disser respeito à função característica das obrigações do mesmo grupo. Reconhece-se ao legislador, de qualquer modo, a prerrogativa de estabelecer diferenciações entre obrigações de um mesmo perfil funcional, o que se verifica, por exemplo, na previsão de prazos prescricionais distintos para variadas pretensões de perfil funcional executório (vejam-se, por exemplo, no art. 206, o inciso I do $\S 1^{\circ}$, os incisos I a III do $\S 3^{\circ}$ e os incisos I e II do $\S 5^{\circ}$ ). Não é, porém, a existência ou não de escolhas legislativas próprias para certas fattispecie de obrigações que irá determinar se elas se originam de uma mesma fonte - mas sim a função por elas desempenhada.

Assim, a eventual omissão (deliberada ou casual) do legislador na previsão de prazos prescricionais distintos para pretensões de idêntico perfil funcional não deve acarretar a incidência do prazo prescricional geral para as pretensões não expressamente reguladas, caso possam elas ser englobadas por uma previsão genérica que sintetize o perfil funcional em questão. Justificase, à luz dessas considerações, a interpretação da noção de "ressarcimento de enriquecimento sem causa" (conforme a redação conferida ao art. 206, $\S 3^{\circ}$, IV, do Código Civil) de modo a traduzir o 
inteiro perfil funcional restitutório. Desse modo, parece adequado concluir pela incidência do prazo prescricional trienal para a generalidade das pretensões restitutórias, decorrentes ou não da cláusula geral do dever de restituir contida no art. 884, desde que não se lhes tenha atribuído prazo específico - tal como sucede, nos exemplos já mencionados, com algumas específicas pretensões de perfil executório.

Como se buscou demonstrar, diante da ausência de escolha expressa do legislador por um prazo prescricional específico para certa hipótese de pretensão restitutória, a solução deve necessariamente ser buscada na previsão destinada a reger a generalidade de hipóteses compreendidas pelo instituto da vedação ao enriquecimento sem causa. Com efeito, independentemente de a específica hipótese de pretensão restitutória remontar de modo direto ao art. 884 do Código Civil, será possível (rectius: necessário) submetê-la ao tratamento unitário dispensado às pretensões que tenham em comum o perfil funcional restitutório. O aludido art. 884 consiste, nesse contexto, em cláusula geral do dever de restituição do enriquecimento sem causa, em convivência harmoniosa com as previsões específicas do dever de restituição nas mais variadas matérias - como sucede precisamente no caso do pagamento indevido. A identificação do perfil funcional comum a todas essas obrigações (a saber, o restitutório) conduz, como visto, à compreensão do art. 206, § $3^{\circ}$, IV, do Código Civil como prazo prescricional aplicável a todas as hipóteses de pretensões restitutórias (remontem elas ou não à cláusula geral do art. 884), ressalvadas aquelas para as quais o legislador, excepcionalmente, haja estabelecido prazo prescricional específico.

Nesse sentido, do ponto de vista funcional, nenhuma distinção há de ser traçada entre o dever de restituir oriundo da declaração de nulidade (total ou parcial) de um negócio jurídico e aquele ensejado pela resolução contratual decorrente do inadimplemento. Em ambos os casos, a restituição de prestações realizadas pelas partes, uma à outra, em cumprimento ao acordo (quando, evidentemente, concluir o julgador que há algo a restituir), deverá ser considerada uma manifestação da fonte obrigacional associada à vedação ao enriquecimento sem causa. Consequentemente, o prazo prescricional aplicável em ambos os casos não pode ser outro senão aquele especificamente previsto para as pretensões restitutórias em geral: o prazo trienal de que trata o art. 206, $\S 3^{\circ}, \mathrm{IV}$, do Código Civil.

\section{REFERÊNCIAS}

AGUIAR JÚNIOR, Ruy Rosado de. Projeto do Código Civil: as obrigações e os contratos. Revista dos Tribunais, São Paulo, v. 89, n. 775, p. 18-31, maio 2000.

ALPA, Guido. Corso di diritto contrattuale. Padova: CEDAM, 2006.

ALVIM, Agostinho. Da inexecução das obrigações e suas consequências. Rio de Janeiro: Editora Jurídica e Universitária, 1965.

ARGIROFFI, Carlo. Caducazione del contratto ad effetti reali. Napoli: ESI, 1984.

BARASSI, Lodovico. La teoria generale delle obbligazioni. Milano: Giuffrè, 1964. v. II. 
BELFIORE, Angelo. Risoluzione per inadempimento e obbligazioni restitutorie. In: SCRITTI in onore di Giuseppe Auletta. Milano: Giuffrè, 1988. v. 2.

BENABENT, Alain. Droit des obligations. Paris: LGDJ, 2016.

BENEDETTI, Enzo. L'arricchimento senza causa. Rivista Trimestrale di Diritto e Procedura Civile, Milano, n. 4, p. 1.652-1.677, dez. 1959.

BIANCA, Massimo. Diritto civile. Milano: Giuffrè, 2000. v. 3.

BOUCARD, Hélène. le nouveau régime de l'inexécution contractuelle. In: SCHULZE, Reiner; WICKER, Guillaume; MÄSCH, Gerald; MAZEAUD, Denis (coord.). La réforme du droit des obligations en France: $5^{\mathrm{e}}$ Journées Franco-Allemandes. Paris: Société de législation comparée, 2015.

CARRESI, Franco. Il contratto. In: MENGONI, Luigi (coord.). Trattato di diritto civile e commerciale, Milano, 1997. v. 21, t. 2.

CORDEIRO, António Menezes. Tratado de direito civil português. Coimbra: Almedina, 2010. v. 2, t. 3-4.

CORDEIRO, António Menezes. Tratado de direito civil. Coimbra: Almedina, 2012. v. I.

COSTA, Judith Martins-. A boa-fé no direito privado: critérios para a sua aplicação. São Paulo: Saraiva, 2018.

COSTA, Judith Martins; HAICAL, Gustavo. Direito restituitório - Pagamento indevido e enriquecimento sem causa - Erro invalidante e erro elemento do pagamento indevido Prescrição. Revista dos Tribunais, São Paulo, n. 956, jun. 2015. Disponível em: http:// dspace/xmlui/bitstream/item/19379/RTDoc\%20\%2015-7-14\%2012_24\%20\%28PM\%29. pdf?sequence=1. Acesso em: 14 julho 2015 .

D'ADDA, Alessandro. Gli obblighi conseguenti alla pronuncia di risoluzione del contratto per inadempimento tra restituzioni e risarcimento. Rivista di Diritto Civile, Milano, v. 46, n. 4, p. 529$571,2000$.

DIAS, José de Aguiar. Da responsabilidade civil. Rio de Janeiro: Lumen Juris, 2012.

DONATELLI, Remo. Vecchie e nuove “categorie" comprese nel "genere" dell'arricchimento senza causa. Giuriusprudenza di Merito, [s. l.], v. 1, p. 540-543, 1995.

ESPÍNOLA, Eduardo. Garantia e extinção das obrigações: obrigações solidárias e indivisíveis. Campinas: Bookseller, 2005.

FRANZONI, Massimo. Trattato della responsabilità civile. Milano: Giuffrè, 2010. v. 2.

GALLO, Paolo. Le restituzioni contrattuali. In: ADDIS, Fabio et al. Studi in onore di Nicolò Lipari. Milano: Giuffrè, 2008. t. 1.

GAZZONI, Francesco. Manuale di diritto civile. Napoli: ESI, 2015. 
GENICON, Thomas. "Résolution" et "résiliation" dans le projet d'ordonnance portant réforme du droit des contrats. Semaine Juridique, Paris, v. 38, 2015.

GIORGIANNI, Michaela. L'arricchimento senza causa nel diritto italiano e tedesco: una regola e due sistemi a confronto. Rivista del Diritto Commerciale e del Diritto Generale delle Obbligazioni, a. CIII, I, 2005.

GOMES, Júlio. O conceito de enriquecimento, o enriquecimento forçado e os vários paradigmas do enriquecimento sem causa. Coimbra: UCP, 1998.

GOMES, Orlando. Contratos. Rio de Janeiro: Forense, 2007.

GOMES, Orlando. Obrigações. Rio de Janeiro: Forense, 1976.

GONDINHO, André Osorio. Codificação e cláusulas gerais. RTDC, Rio de Janeiro, v. 1, n. 2, p. 3-25, abr./jun., 2000.

KONDER, Carlos Nelson. Enriquecimento sem causa e pagamento indevido. In: TEPEDINO, Gustavo (coord.). Obrigações: estudos na perspectiva civil-constitucional. Rio de Janeiro: Renovar, 2005. p. 379.

LARROUMET, Christian; BROS, Sarah. Traité de droit civil. Paris: Economica, 2016. t. 3.

LEITÃO, Luís Manuel Teles de Menezes. Direito das obrigações. Coimbra: Almedina, 2010. v. 2.

LEITÃO, Luís Manuel Teles de Menezes. O enriquecimento sem causa no direito civil: estudo dogmático sobre a viabilidade da configuração unitária do instituto, face à contraposição entre as diferentes categorias de enriquecimento sem causa. Lisboa: Centro de Estudos Fiscais, 1996.

MALAURIE, Philippe; AYNÈS, Laurent; STOFFEL-MUNCK, Philippe. Droit des obligations. Paris: LGDJ, 2015.

MAZEAUD, Henri et al. Leçons de droit civil. Paris: Montchrestien, 1985. v. 1, t. 2.

MICHELON JR., Cláudio. Direito restituitório: enriquecimento sem causa, pagamento indevido, gestão de negócios. São Paulo: Revista dos Tribunais, 2007.

MIRAGEM, Bruno. Direito civil: direito das obrigações. São Paulo: Saraiva, 2017.

MIRAGEM, Bruno. Pretensão de repetição de indébito do consumidor e sua inserção nas categorias gerais do direito privado: comentário à Súmula 322 do STJ. Revista de Direito do Consumidor, São Paulo, v. 79, p. 385-402, jul./set. 2011.

MOSCATI, Enrico. Studi sull'indebito e sull'arricchimento senza causa. Padova: CEDAM, 2012.

NORONHA, Fernando. Direito das obrigações. São Paulo: Saraiva, 2013.

PARDOLESI, Paolo. Rimedi che non rimediano e alternative risarcitorie: il disgorgement dei profitti da inadempimento. Rivista Critica del Diritto Privato, Milano, v. 25, n. 3, set. 2007.

PEREIRA, Caio Mário da Silva. Instituições de direito civil. Rio de Janeiro: GEN, 2020. v. 1. 
PEREIRA, Caio Mário da Silva. Responsabilidade civil. Rio de Janeiro: Forense, 2016.

PERLINGIERI, Pietro. Manuale di diritto civile. Napoli: Edizioni Scientifiche Italiane, 2014.

PINTO, Paulo Mota. Interesse contratual negativo e interesse contratual positivo. Coimbra: Coimbra Editora, 2008. v. 2.

RODRIGUES, Silvio. Direito civil. São Paulo: Max Limonad, 1964. v. 2.

ROPPO, Vincenzo. Rimedi - 2. In: ROPPO, Vincenzo. Trattato del contratto. Milano: Giuffrè, 2006. v. 5.

SANTOS, J. M. de Carvalho. Código Civil brasileiro interpretado. Rio de Janeiro: Freitas Bastos, 1986. v. 15.

SCHREIBER, Anderson. Novos paradigmas da responsabilidade civil: da erosão dos filtros da reparação à diluição dos danos. 6. ed. São Paulo: Atlas, 2015.

SICCHIERO, Gianluca. La risoluzione per inadempimento: artt. 1453-1459. In: BUSNELLI, Francesco D. (coord.). Il Codice Civile: commentario. Milano: Giuffrè, 2007.

SILVA, Rodrigo da Guia. Cláusula geral de restituição do enriquecimento sem causa. Revista de Direito Privado, São Paulo, v. 103, p. 191-237, jan./fev. 2020.

SILVA, Rodrigo da Guia. Cláusulas de não restituir versus cláusulas de não indenizar: perspectivas de delimitação dogmática a partir de uma análise funcional dos efeitos da resolução contratual.

Revista IBERC, [s. l.], v. 2, n. 1, p. 1-34, jan./abr. 2019a.

SILVA, Rodrigo da Guia. Enriquecimento sem causa: as obrigações restitutórias no direito civil. São Paulo: Thomson Reuters Brasil, 2018a.

SILVA, Rodrigo da Guia. Invalidade do negócio jurídico e obrigação de restituição. In: TEPEDINO, Gustavo; OLIVA, Milena Donato (org.). Teoria geral do direito civil: questões controvertidas. Belo Horizonte: Fórum, 2018b. p. 253-281.

SILVA, Rodrigo da Guia. Prazo prescricional da pretensão de repetição de indébito: um diálogo necessário entre pagamento indevido e enriquecimento sem causa. Civilistica.com, Rio de Janeiro, v. 8, n. 2, p. 1-22, 2019 b.

SIMLER, Philippe. Commentaire de la réforme du droit des contrats et des obligations. Paris: LexiNexis, 2016.

SOUZA, Eduardo Nunes de. De volta à causa contratual: aplicações da função negocial nas invalidades e nas vicissitudes supervenientes do contrato. Civilistica.com, Rio de Janeiro, v. 8, n. 2, p. 1-53, 2019.

SOUZA, Eduardo Nunes de. Nexo causal e culpa na responsabilidade civil: subsídios para uma necessária distinção conceitual. Civilistica.com, Rio de Janeiro, v. 7, n. 3, p. 1-58, 2018.

SOUZA, Eduardo Nunes de. Teoria geral das invalidades do negócio jurídico: nulidade e anulabilidade no direito civil contemporâneo. São Paulo: Almedina, 2017a. 
SOUZA, Eduardo Nunes de. Uma releitura funcional das invalidades do negócio jurídico: proposta de modulação dos efeitos de atos nulos e anuláveis. Civilistica.com, Rio de Janeiro, v. 6, n. 1, p. $1-48,2017 b$.

SOUZA, Eduardo Nunes de; SILVA, Rodrigo da Guia. Notas sobre a autonomia funcional da responsabilidade civil. In: MATOS, Ana Carla Harmatiuk; TEIXEIRA, Ana Carolina Brochado; TEPEDINO, Gustavo (org.). Direito Civil, Constituição e unidade do sistema. Belo Horizonte: Fórum, 2018.

TEPEDINO, Gustavo. A evolução da responsabilidade civil no direito brasileiro e suas controvérsias na atividade estatal. Temas de direito civil. 4. ed. Rio de Janeiro: Renovar, 2008.

TEPEDINO, Gustavo; BARBOZA, Heloisa Helena; MORAES, Maria Celina Bodin de. Código civil interpretado conforme a constituição da república. Rio de Janeiro: Renovar, 2012. v. 2.

TEPEDINO, Gustavo; SCHREIBER, Anderson; FRADERA, Vera. La rupture du contrat: rapport brésilien. Le contrat. Paris: Société de Législation Comparée, 2005.

TERRÉ, François; SIMLER, Philippe; LEQUETTE, Yves. Droit civil: les obligations. Paris: Dalloz, 2013.

TRIMARCHI, Pietro. Il contratto: inadempimento e rimedi. Milano: Giuffrè, 2010.

TRIMARCHI, Pietro. Sulla struttura e sulla funzione della responsabilità per arricchimento senza causa. Rivista di Diritto Civile, Milano, v. 8, n. 3, p. 227-251, maio/jun. 1962.

Como citar: SOUZA, Eduardo Nunes de; SILVA, Rodrigo da Guia. Uma aplicação da disciplina do enriquecimento sem causa às hipóteses de extinção contratual: o prazo prescricional da pretensão restitutória. Scientia Iuris, Londrina, v. 25, n. 2, p. 83-106, jul. 2021. DOI 10.5433/21788189.2021v25n2p83. ISSN: 2178-8189.

Recebido em 02/11/2020

Aprovado em 03/07/2021 